\title{
HUBUNGAN ANTARA KOORDINASI MATA-TANGAN, KEKUATAN OTOT PERUT DAN PERSEPSI KINESTETIK DENGAN \\ KETERAMPILAN PASSING ATAS BOLA VOLI PADA SISWA PUTRA KELAS 4-5 SD NEGERI 2 SARIMULYO BOYOLALI TAHUN 2019
}

\author{
Muh. Ikhwan Iskandar \\ PKO FKIP UTP Surakarta \\ hariyani.kuncoro@gmail.com
}

\begin{abstract}
ABSTRAK
Tujuan dari penelitian ini adalah untuk mengetahui: (1) Hubungan antara Koordinasi Mata-Tangan Dengan Keterampilan Passing Atas Bola Voli Pada Siswa Putra Kelas 4-5 SD Negeri 2 Sarimulyo Boyolali Tahun 2019 (2) Hubungan antara Kekuatan Otot Perut Dengan Keterampilan Passing Atas Bola Voli Pada Siswa Putra Kelas 4-5 SD Negeri 2 Sarimulyo Boyolali Tahun 2019 (3) Hubungan antara Persepsi Kinestetik Dengan Keterampilan Passing Atas Bola Voli Pada Siswa Putra Kelas 4-5 SD Negeri 2 Sarimulyo Boyolali Tahun 2019 (4) Hubungan Antara Koordinasi Mata-Tangan, Kekuatan Otot Perut Dan Persepsi Kinestetik Dengan Keterampilan Passing Atas Bola Voli Pada Siswa Putra Kelas 4-5 SD Negeri 2 Sarimulyo Boyolali Tahun 2019.

Penelitian ini menggunakan metode deskriptif studi korelasional. Penelitian ini dilaksanakan di Lapangan SD Negeri 2 Sarimulyo Boyolali pada Siswa Putra Kelas 4-5 SD Negeri 2 Sarimulyo Boyolali. Penelitian ini dilaksanakan pada bulan Februari tahun 2019. Dalam penelitian ini variabel bebas disebut juga sebagai prediktor dan variabel terikat yang disebut juga sebagai kriterium. Teknik pengumpulan data dalam penelitian ini adalah menggunakan teknik tes dan pengukuran. Adapun jenis tes yang digunakan adalah: (1) koordinasi mata-tangan dengan tes memantulkan bola ke tembok dari Mulyono B, (1988:78), (2) kekuatan otot perut dengan tes Sit-Up dari Barry L. Jhonson \& Jack K, Nelson, (1986:133), (3) Tes Persepsi Kinestetik bidang vertical untuk mengukur persepsi kinestetik (Barry L. Johnson and Jack K. Nelson, 1986: 189-190), (4) Tes passing atas yang digunakan dalam penelitian ini menggunakan tes passing atas dari Suharno HP,( $1984: 71$ ).

Berdasarkan analisis data dan pengujian hipotesis yang telah dilakukan, maka simpulan yang dapat diperoleh adalah: (1) Ada hubungan yang signifikan antara Koordinasi mata tangan dengan Passing atas, $r_{\text {hitung }}=0.410>r_{\text {tabel }} \%=0,361$. (2) Ada hubungan yang signifikan antara Kekuatan otot perut dengan Passing atas, $r_{\text {hitung }}=0.402>r_{\text {tabel } 5 \%}=0,361$. (3) Ada hubungan yang signifikan antara Persepsi kinestetik dengan Passing atas termasuk data inversi karena lebih kecil dari $r$ tabel, $\mathrm{r}_{\text {hitung }}=-0.497<\mathrm{r}_{\text {tabel }} \%=0,361$. (4) Ada hubungan yang signifikan antara Koordinasi mata tangan, Kekuatan otot perut dan Persepsi kinestetik dengan Passing atas, $\mathrm{R}_{\mathrm{y}(123)}^{2}$ sebesar $0.498>\mathrm{r}_{\text {tabel5 }} \%$ pada taraf signifikansi $5 \%$ sebesar 0.361 dan $\mathrm{F}_{0}$ sebesar $8.6248>\mathrm{f}_{\text {tabel }}$ pada taraf signifikansi $5 \%$ sebesar 2,89.
\end{abstract}

Kata kunci : Kekuatan otot perut, Persepsi kinestetik dan Passing 


\section{Hubungan Antara Koordinasi Mata-Tangan, Kekuatan Otot Perut Dan Persepsi Kinestetik Dengan Keterampilan Passing Atas Bola Voli Pada Siswa Putra Kelas 4-5 Sd Negeri 2 Sarimulyo Boyolali Tahun 2019}

\section{Muh. Ikhwan Iskandar}

\section{PENDAHULUAN}

Di Indonesia permainan bola voli sudah sangat merakyat. Hal itu disebabkan peralatannya yang relatif mudah dan murah serta permainan tersebut juga enak untuk ditonton dan dipraktekkan secara bersama-sama untuk tujuan pengisi waktu luang, hiburan, rekreasi, pendidikan bahkan untuk tujuan prestasi walaupun, tidak dapat dipungkiri, bahwa rata-rata masyarakat Indonesia masih memainkan olahraga ini dengan tujuan untuk hiburan dan pada waktu luang saja.

Hampir di setiap pelosok desa sampai dengan kota kabupaten, banyak dijumpai lapangan bola voli. Namun sayangnya secara umum berdasarkan pengamatan, belum kelihatan adanya pembinaan yang benar sehingga kualitas dalam bermain bola voli masih belum kelihatan baik atau dengan lain perkataan, para penduduk dalam bermain bola voli belum menggunakan teknik-teknik yang benar, sehingga hasilnya tidak optimal.

Di SD Negeri 2 Sarimulyo Boyolali Tahun 2019, permainan bola voli juga dilatihkan kepada para siswanya. Dan rata-rata para siswa juga menggemari permainan bola voli ini. Siswa Putra telah mendapatkan pelatihan bola voli dan bahkan mereka telah diberi progam latihan passing atas selama hampir 2 bulan dalam rangka pemberian perlakuan untuk penelitian eksperimen. Sehingga dapat dikatakan, siswa tersebut sudah mahir melakukan keterampilan passing atas dengan baik. Hal inilah yang kemudian membuat peneliti tertarik untuk mengadakan penelitian lanjutan yakni jenis penelitian korelasional. Maksudnya adalah peneliti tertarik mengadakan penelitian mengenai teknik passing atas yang telah dikuasai oleh para siswa putra Kelas 4-5 SD Negeri 2 Sarimulyo Boyolali Tahun 2019 tersebut, dengan menghubungkan unsur-unsur kondisi fisik yang mendukung didalam proses pelaksanaan teknik keterampilan gerak passing atas.

Menurut Suharno H.P., (1995: 20) "unsur-unsur kondisi fisik yang mendukung kemampuan teknik keterampilan bola voli adalah: kekuatan, daya tahan, kecepatan, kekuatan otot perut, kelentukan, daya iedak, koordinasi, ketepatan, dan stamina”. Sedang menumt Sugiyanto (1994: 4) mengutip pendapat Anita J. Harrow “yang membagi 6 klasifikasi gerakan tubuh yaitu: gerak refleks, 


\section{Hubungan Antara Koordinasi Mata-Tangan, Kekuatan Otot Perut Dan Persepsi Kinestetik Dengan Keterampilan Passing Atas Bola Voli Pada Siswa Putra Kelas 4-5 Sd Negeri 2 Sarimulyo Boyolali Tahun 2019}

\section{Muh. Ikhwan Iskandar}

gerak dasar manusia, kemampuan perseptual, kemampuan fisik, gerak keterampilan, dan komunikasi non diskursif".

Dalam hal ini peneliti akan memfokuskan penelitian pada unsur kondisi fisik kekuatan, serta klasifikasi gerakan tubuh kemampuan persepsual yang masih dibagi menjadi lima macam yaitu: pembedaan rasa gerak (kinestetik), pembedaan penglihat (visual), pembedaan pendengar (auditori), pembedaan peraba (taktil), dan kemampuan koordinasi. Peneliti mengambil kemampuan persepsual yang pembedaan rasa gerak kinestetik dengan menyebut persepsi kinestetik.

"Teknik memainkan bola voli meliputi: passing, set-up, servis, umpan dan block" (Soedarwo dan Soeyati, 1991: 15). Teknik pass atas adalah teknik dasar dalam permainan bola voli yang berperan untuk membantu menyerang dengan baik. Tanpa adanya penguasaan teknik passing atas, maka regu atau tim bola voli, dalam. hal ini pengumpan atau tosser tidak akan dapat melakukan atau menjalankan tugasnya dengan efektif, oleh karena tidak adanya bola "enak" yang dapat diumpankan kepada smasher.

\section{METODE PENELITIAN}

Metode yang digunakan dalam penelitian ini adalah metode deskriptif dengan studi korelasi, yang mana disebutkan bahwa tujuan dari penelitiannya adalah untuk mencari ada tidaknya hubungan antara variable bebas dan variable terikat. Sebagai variable bebas adalah koordinasi mata-tangan, kekuatan otot perut dan persepsi kinestetik, sedangkan variable terikatnya keterampilan passing atas.

\section{HASIL PENELITIAN}

\section{Deskripsi Data}

Data yang diperoleh dari tiap-tiap variabel tersebut kemudian dikelompokkan dan dianalisis dengan statistik, seperti terlihat pada lampiran. Adapun rangkuman deskripsi data secara keseluruhan akan disajikan sebagai berikut: 
Hubungan Antara Koordinasi Mata-Tangan, Kekuatan Otot Perut Dan Persepsi Kinestetik Dengan Keterampilan Passing Atas Bola Voli Pada Siswa Putra Kelas 4-5 Sd Negeri 2 Sarimulyo Boyolali Tahun 2019

\section{Muh. Ikhwan Iskandar}

Tabel 1. Deskripsi Data Hasil Tes Koordinasi mata tangan, Kekuatan otot perut dan Persepsi kinestetik dan Passing atas.

\begin{tabular}{|c|c|c|c|c|c|c|}
\hline Variabel & Tes & $\mathrm{N}$ & Mean & SD & $\begin{array}{c}\text { Nilai } \\
\text { Tertinggi }\end{array}$ & $\begin{array}{c}\text { Nilai } \\
\text { Terendah }\end{array}$ \\
\hline \multirow{2}{*}{ Koordinasi mata tangan } & Test & 30 & 19.13 & 3.17 & 25 & 14 \\
\cline { 2 - 7 } & Re-test & 30 & 20.93 & 3.06 & 27 & 16 \\
\hline \multirow{2}{*}{ Kekuatan otot perut } & Test & 30 & 30.07 & 5.45 & 40 & 20 \\
\cline { 2 - 7 } & Re-test & 30 & 32.10 & 5.45 & 42 & 22 \\
\hline \multirow{2}{*}{ Persepsi kinestetik } & Test & 30 & 2.57 & 1.92 & 7 & 0 \\
\cline { 2 - 7 } & Re-test & 30 & 4.23 & 1.77 & 8 & 0 \\
\hline \multirow{2}{*}{ Passing atas } & Test & 30 & 6.10 & 2.26 & 9 & 2 \\
\cline { 2 - 7 } & Re-test & 30 & 7.53 & 1.66 & 9 & 4 \\
\hline
\end{tabular}

\section{Uji Reliabilitas}

Uji reliabilitas bertujuan untuk mengetahui tingkat keajegan hasil tes masing-masing variabel yang dilakukan dalam penelitian. Hasil uji reliabilitas tes dan re-test Koordinasi mata tangan, Kekuatan otot perut dan Persepsi kinestetik dan Passing atas kemudian dikategorikan, dengan menggunakan pedoman tabel koefisien korelasi dari Book Walter yang dikutip Mulyono Biyakto Atmojo (2008: 22), yaitu:

Tabel 2. Range Kategori Reliabilitas

\begin{tabular}{|c|c|}
\hline Kategori & Reliabilitas \\
\hline Tinggi Sekali & $0,90-1,00$ \\
\hline Tinggi & $0,80-0,89$ \\
\hline Cukup & $0,60-0,79$ \\
\hline Kurang & $0,40-0,59$ \\
\hline Tidak Signifikan & $0,00-0,39$ \\
\hline
\end{tabular}


Hubungan Antara Koordinasi Mata-Tangan, Kekuatan Otot Perut Dan Persepsi Kinestetik Dengan Keterampilan Passing Atas Bola Voli Pada Siswa Putra Kelas 4-5 Sd Negeri 2 Sarimulyo Boyolali Tahun 2019

\section{Muh. Ikhwan Iskandar}

Hasil uji reliabilitas data Kekuatan otot lengan, Kekuatan otot perut dan Persepsi kinestetik dan Passing atas pada penelitian ini adalah:

Tabel 3. Ringkasan Hasil Uji Reliabilitas Data

\begin{tabular}{|l|c|c|}
\hline \multicolumn{1}{|c|}{ Variabel } & Reliabilita & Kategori \\
\hline Koordinasi mata tangan & 0.981 & Tinggi Sekali \\
\hline Kekuatan otot perut & 0.999 & Tinggi Sekali \\
\hline Persepsi kinestetik & 0.838 & Tinggi \\
\hline Passing atas & 0.960 & Tinggi Sekali \\
\hline
\end{tabular}

\section{Pengujian Persyaratan Analisis}

Sebelum analisis data dilakukan uji persyaratan analisis. Untuk analisis regresi diperlukan uji persyaratan analisis yaitu normalitas penyebaran nilai dan persyaratan linieritas hubungan antara prediktor dengan kriterium. Hasil pengujian persyaratan analisis pada penelitian ini adalah sebagai berikut:

\section{Uji Normalitas}

Uji normalitas data dalam penelitian ini menggunakan chi-kuadrat. Adapun hasil uji normalitas yang dilPersepsi kinestetik kan pada hasil tes Koordinasi mata tangan $\left(\mathrm{X}_{1}\right)$, Kekuatan otot perut $\left(\mathrm{X}_{2}\right)$, Persepsi kinestetik $\left(\mathrm{X}_{3}\right)$ dan Passing atas $(\mathrm{Y})$ pada penelitian ini adalah:

Tabel 4. Rangkuman Hasil Uji Normalitas Data

\begin{tabular}{|l|c|c|c|c|c|c|}
\hline \multicolumn{1}{|c|}{ Variabel } & $\mathrm{Db}$ & $\mathrm{M}$ & $\mathrm{SD}$ & $\chi^{2}$ hitung & $\chi^{2}$ tabel 5\% & Simpulan \\
\hline Koordinasi mata tangan & $6-1=5$ & 19.13 & 3.17 & 2.358 & 11,070 & $\begin{array}{c}\text { Berdistribusi } \\
\text { normal }\end{array}$ \\
\hline Kekuatan otot perut & $6-1=5$ & 30.07 & 5.45 & 3.245 & 11,070 & $\begin{array}{c}\text { Berdistribusi } \\
\text { normal }\end{array}$ \\
\hline Persepsi kinestetik & $6-1=5$ & 2.57 & 1.92 & 2.578 & 11,070 & $\begin{array}{c}\text { Berdistribusi } \\
\text { normal }\end{array}$ \\
\hline Passing atas & $6-1=5$ & 6.10 & 2.26 & 2.167 & 11,070 & $\begin{array}{c}\text { Berdistribusi } \\
\text { normal }\end{array}$ \\
\hline
\end{tabular}




\section{Hubungan Antara Koordinasi Mata-Tangan, Kekuatan Otot Perut Dan Persepsi Kinestetik Dengan Keterampilan Passing Atas Bola Voli Pada Siswa Putra Kelas 4-5 Sd Negeri 2 Sarimulyo Boyolali Tahun 2019}

\section{Muh. Ikhwan Iskandar}

Dari hasil uji normalitas yang dilakukan pada tiap-tiap variabel tersebut dapat diketahui bahwa nilai chi-kuadrat yang diperoleh $\left(\chi^{2}\right.$ hitung $)$ pada variabel Koordinasi mata tangan $\left(\mathrm{X}_{1}\right)$, Kekuatan otot perut $\left(\mathrm{X}_{2}\right)$, Persepsi kinestetik $\left(\mathrm{X}_{3}\right)$ dan Passing atas (Y) lebih kecil dari nilai chi-kuadrat dalam tabel $\left(\chi^{2}\right.$ tabel $\left.5 \%\right)$. Dengan demikian hipotesis nol diterima. Yang berarti bahwa data hasil tes Koordinasi mata tangan $\left(\mathrm{X}_{1}\right)$, Kekuatan otot perut $\left(\mathrm{X}_{2}\right)$, Persepsi kinestetik $\left(\mathrm{X}_{3}\right)$ dan Passing atas $(\mathrm{Y})$ termasuk berdistribusi normal.

\section{Uji Linieritas}

Uji linieritas hubungan antara masing-masing prediktor yaitu Koordinasi mata tangan $\left(\mathrm{X}_{1}\right)$, Kekuatan otot perut $\left(\mathrm{X}_{2}\right)$, Persepsi kinestetik $\left(\mathrm{X}_{3}\right)$, dengan kriterium yaitu Passing atas (Y) dilakukan dengan analisis varians. Rangkuman hasil uji linieritas tersebut dapat dilihat dalam tabel sebagai berikut:

Tabel 5. Rangkuman Hasil Analisis Varians Untuk Uji Linieritas Hubungan Antara Prediktor dengan Kriterium

\begin{tabular}{|c|c|c|c|c|}
\hline Variabel & $\mathrm{db}$ & $\mathrm{F}_{\text {hitung }}$ & $\mathrm{F}_{\text {tabel } 5 \%}$ & Simpulan \\
\hline $\mathrm{X}_{1} \mathrm{Y}$ & $4: 24$ & 0.19 & 2,78 & Model linier diterima \\
\hline $\mathrm{X}_{2} \mathrm{Y}$ & $13: 15$ & 0.82 & 2,43 & Model linier diterima \\
\hline $\mathrm{X}_{3} \mathrm{Y}$ & $20: 8$ & 1.72 & 3,15 & Model linier diterima \\
\hline
\end{tabular}

Dari rangkuman hasil uji linieritas tersebut dapat diketahui bahwa nilai $F_{\text {hitung }}$ linieritas yang diperoleh dari tiap variabel lebih kecil dari harga $F_{\text {tabel }} \%$. Dengan demikian hipotesis nol linieritas ketiga variabel tersebut diterima. Berarti bahwa baik korelasi antara $\mathrm{X}_{1} \mathrm{Y}, \mathrm{X}_{2} \mathrm{Y}$ dan $\mathrm{X}_{3} \mathrm{Y}$ berbentuk linier. 


\section{Hubungan Antara Koordinasi Mata-Tangan, Kekuatan Otot Perut Dan Persepsi Kinestetik Dengan Keterampilan Passing Atas Bola Voli Pada Siswa Putra Kelas 4-5 Sd Negeri 2 Sarimulyo Boyolali Tahun 2019}

\section{Muh. Ikhwan Iskandar}

\section{Hasil Analisis Data}

Hasil analisis korelasi dan analisis regresi antara data tes Koordinasi mata tangan $\left(\mathrm{X}_{1}\right)$, Kekuatan otot perut $\left(\mathrm{X}_{2}\right)$, Persepsi kinestetik $\left(\mathrm{X}_{3}\right)$ dengan Passing atas (Y) penelitian ini adalah:

\section{Analisis Korelasi Tiap Prediktor}

Hasil analisis korelasi masing-masing prediktor dengan kriterium penelitian ini adalah sebagai berikut:

a. Berdasarkan analisis korelasi antara Koordinasi mata tangan $\left(\mathrm{X}_{1}\right)$ dengan Passing atas (Y), diperoleh koefisien korelasi sebesar 0.410. Dengan $\mathrm{N}=30$, nilai $\mathrm{r}_{\text {tabel }} 5 \%=0,361$. Ternyata $\mathrm{r}_{\text {hitung }}=0.410>\mathrm{r}_{\text {tabel }} \%=0,361$. Hal ini menunjukkan bahwa terdapat hubungan yang signifikan antara Koordinasi mata tangan $\left(\mathrm{X}_{1}\right)$ dengan Passing atas $(\mathrm{Y})$.

b. Berdasarkan analisis korelasi antara Kekuatan otot perut $\left(\mathrm{X}_{2}\right)$ dengan Passing atas $(\mathrm{Y})$, diperoleh koefisien korelasi sebesar 0.402. Dengan $\mathrm{N}=30$, nilai $\mathrm{r}_{\text {tabel }}$ $5 \%=0,361$. Ternyata $r_{\text {hitung }}=0.402>r_{\text {tabel }} \%=0,361$. Hal ini menunjukkan bahwa terdapat hubungan yang signifikan antara Kekuatan otot perut $\left(\mathrm{X}_{2}\right)$ dengan Passing atas (Y).

c. Berdasarkan analisis korelasi antara Persepsi kinestetik $\left(\mathrm{X}_{3}\right)$ dengan Passing atas (Y), diperoleh koefisien korelasi sebesar -0.497. Dengan $\mathrm{N}=30$, nilai $\mathrm{r}_{\text {tabel }}$ $5 \%=0,361$. Ternyata $r_{\text {hitung }}=-0.497<r_{\text {tabel }} \%=0,361$. Hal ini menunjukkan bahwa terdapat hubungan yang signifikan antara Persepsi kinestetik $\left(\mathrm{X}_{3}\right)$ dengan Passing atas (Y).

Ringkasan hasil analisis korelasi masing-masing prediktor dengan kriterium penelitian ini adalah sebagai berikut:

Tabel 6. Rangkuman Hasil Analisis Korelasi Tiap Prediktor dengan Kriterium

\begin{tabular}{|c|c|c|c|}
\hline Variabel & $r_{\text {hitung }}$ & $r_{\text {tabel }}$ & Simpulan \\
\hline $\mathrm{X}_{1} \mathrm{Y}$ & 0.410 & 0,361 & Korelasi signifikan \\
\hline $\mathrm{X}_{2} \mathrm{Y}$ & 0.402 & 0,361 & Korelasi signifikan \\
\hline $\mathrm{X}_{3} \mathrm{Y}$ & -0.497 & 0,361 & Korelasi signifikan \\
\hline
\end{tabular}




\section{Hubungan Antara Koordinasi Mata-Tangan, Kekuatan Otot Perut Dan Persepsi Kinestetik Dengan Keterampilan Passing Atas Bola Voli Pada Siswa Putra Kelas 4-5 Sd Negeri 2 Sarimulyo Boyolali Tahun 2019}

\section{Muh. Ikhwan Iskandar}

\section{Analisis Regresi}

Analisis regresi yang dilakukan pada penelitian ini menggunakan analisis regresi ganda tiga prediktor. Hasil analisis regresi antara data tes Persepsi kinestetik $\left(\mathrm{X}_{1}\right)$, Koordinasi mata tangan $\left(\mathrm{X}_{2}\right)$, Kekuatan otot perut $\left(\mathrm{X}_{3}\right)$ Persepsi kinestetik dengan Passing atas (Y) penelitian ini adalah sebagai berikut:

a. Persamaan garis regresinya adalah:

$$
\hat{\mathrm{y}}=\quad 0.217 \mathrm{X}_{1}+\quad-0.006 \mathrm{X}_{2}+0.055 \mathrm{X}_{3}+2.001
$$

b. Koefisien korelasi dan determinasi antara prediktor dan kriterium:

$$
\begin{aligned}
& R_{y(1,2,3)}=0.706 \\
& R_{y(1,2,3)}^{2}=0.498
\end{aligned}
$$

c. Uji signifikansi analisis regresi.

Hasil uji signifikansi regresi penelitian ini dapat dilihat pada tabel berikut :

Tabel 7. Ringkasan Hasil Analisis Regresi

\begin{tabular}{|c|c|c|c|c|}
\hline Sumber Variasi & db & JK & RK & Freg \\
\hline Regresi (reg) & 3 & 74.1699 & 24.7233 & 8.6248 \\
\hline Residu (res) & 26 & 74.5301 & 2.8665 & - \\
\hline Total & 29 & 148.7000 & - & - \\
\hline
\end{tabular}

Dari hasil analisis regresi tersebut dapat disimpulkan, dengan $\mathrm{db}=\mathrm{m}$ lawan $\mathrm{N}-\mathrm{m}-1=3$ lawan 26, harga $\mathrm{F}_{\text {tabel }}$ \% adalah 2,89. Sedangkan nilai $\mathrm{F}$ yang diperoleh adalah 8.6248 , ternyata lebih besar dari angka batas penolakan hipotesa nol. Dengan demikian hipotesa nol ditolak, yang berarti bahwa terdapat hubungan yang signifikan antara Koordinasi mata tangan $\left(\mathrm{X}_{1}\right)$, Kekuatan otot perut $\left(\mathrm{X}_{2}\right)$, Persepsi kinestetik $\left(\mathrm{X}_{3}\right)$ dengan Passing atas $(\mathrm{Y})$. Adapun besarnya nilai $\mathrm{R}^{2}$ antara Koordinasi mata tangan $\left(\mathrm{X}_{1}\right)$, Kekuatan otot perut $\left(\mathrm{X}_{2}\right)$, Persepsi kinestetik $\left(\mathrm{X}_{3}\right)$ dengan Passing atas (Y) adalah 0.498. 
Hubungan Antara Koordinasi Mata-Tangan, Kekuatan Otot Perut Dan Persepsi Kinestetik Dengan Keterampilan Passing Atas Bola Voli Pada Siswa Putra Kelas 4-5 Sd Negeri 2 Sarimulyo Boyolali Tahun 2019

Muh. Ikhwan Iskandar

\section{Pengujian Hipotesis dan Pembahasan}

\section{Hubungan Antara Koordinasi mata tangan dengan Passing atas}

Dari hasil analisis korelasi pada data Koordinasi mata tangan dengan Passing atas, diperoleh nilai r sebesar 0.410, dimana nilai tersebut lebih besar dari nilai $r_{\text {tabel }}$ pada taraf signifikansi 5\% yaitu 0,361. Karena nilai $r_{\text {hitung }}>r_{\text {tabel }}$, maka nilai korelasi signifikan. Hal ini berarti bahwa perubahan variansi Passing atas dipengaruhi oleh komponen variansi Koordinasi mata tangan.

\section{Hubungan Antara Kekuatan otot perut dengan Passing atas}

Berdasarkan hasil analisis yang telah dilakukan terhadap data Kekuatan otot perut terhadap Passing atas, diperoleh nilai $r$ sebesar 0.402 , dimana nilai tersebut lebih besar dari nilai $r_{\text {tabel }}$ pada taraf signifikansi $5 \%$ yaitu 0,361 . Karena nilai $r_{\text {hitung }}>r_{\text {tabel, }}$, maka nilai korelasi signifikan. Hal ini berarti bahwa variansi unsur Kekuatan otot perut berpengaruh terhadap peningkatan variansi Passing atas.

\section{Hubungan Antara Persepsi kinestetik dengan Passing atas}

Berdasarkan hasil analisis yang telah dilakukan terhadap data Persepsi kinestetik terhadap Passing atas, diperoleh nilai r sebesar -0.497 , dimana nilai tersebut lebih besar dari nilai $r_{\text {tabel }}$ pada taraf signifikansi $5 \%$ yaitu 0,361 . Karena nilai $r_{\text {hitung }}<r_{\text {tabel, }}$ maka nilai korelasi signifikan. Dengan demikian dapat disimpulkan bahwa Persepsi kinestetik memiliki hubungan yang signifikan terhadap Passing atas.

\section{Hubungan Koordinasi mata tangan, Kekuatan otot perut dan Persepsi} kinestetik dengan Passing atas

Pada Hipotesis dinyatakan bahwa hubungan antara Koordinasi mata tangan, Kekuatan otot perut dan Persepsi kinestetik dengan Passing atas di ketahui $\mathrm{R}_{\mathrm{y}(123)}^{2}=0.498$ sedangkan $\mathrm{r}_{\text {tabel }}$ pada taraf signifikasi 0,05 dan $\mathrm{n}=30$ di dapat $\mathrm{r}_{\text {tabel }}$

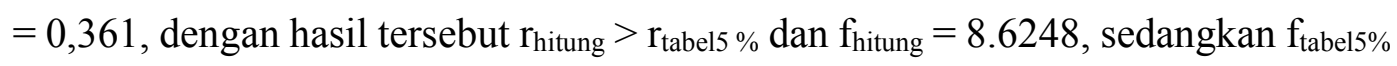
dengan $\mathrm{db} 3: 26=2,89$, ini berarti $\mathrm{F}_{0}>\mathrm{F}_{\text {tabel5\% }}$ Maka hipotesis di terima. 


\section{Hubungan Antara Koordinasi Mata-Tangan, Kekuatan Otot Perut Dan Persepsi Kinestetik Dengan Keterampilan Passing Atas Bola Voli Pada Siswa Putra Kelas 4-5 Sd Negeri 2 Sarimulyo Boyolali Tahun 2019}

\section{Muh. Ikhwan Iskandar}

\section{SIMPULAN}

Berdasarkan hasil penelitian dan hasil analisis regresi dan korelasi product moment yang telah dilPersepsi kinestetik kan dapat diperoleh simpulan sebagai berikut:

1. Ada hubungan yang signifikan antara Koordinasi mata tangan dengan Passing atas, rhitung $=0.410>$ rtabel $5 \%=0,361$.

2. Ada hubungan yang signifikan antara Kekuatan otot perut dengan Passing atas, rhitung $=0.402>$ rtabel $5 \%=0,361$.

3. Ada hubungan yang signifikan antara Persepsi kinestetik dengan Passing atas termasuk data inversi karena lebih kecil dari $r$ tabel, rhitung $=-0.497<$ rtabel $5 \%=0,361$.

4. Ada hubungan yang signifikan antara Koordinasi mata tangan, Kekuatan otot perut dan Persepsi kinestetik dengan Passing atas, R2y(123) sebesar $0.498>$ rtabel5 \% pada taraf signifikansi 5\% sebesar 0.361 dan F0 sebesar $8.6248>$ ftabel pada taraf signifikansi 5\% sebesar 2,89.

\section{DAFTAR PUSTAKA}

M. Yunus. 1991/1992. Olahraga Pilihan Bola Voli. Jakarta: Dirjen Dikti.

M. Maryanti. 1994. Pedoman Atlet. Terjemahan Redaktur Dahara Prize. Semarang: Dahara Prize.

Muller, Harald and Ritzdorf, Walfgang. 2000. Lari, Lompat, Lempar. Jakarta: IAAF-RDC.

Pate, Rusel R., McClenaghan, Bruce. \& Rotella, Robert. 1993. Scientific Foundations of Coaching (Terjemahan Kasiyo Dwijoyonoto). Semarang: IKIP Semarang Press

Soedarwo dan Soeyati. 1991. Teori dan Praktek Bola Voli II. Suarakarta: UNS Press.

Sudjana.1996. Metoda Statistika. Bandung: Penerbit Tarsito.

Sugiyanto. 1991/1992. Ilmu Kepelatihan Olahraga. Yogyakarta: Institut Keguruan dan Ilmu Pendidikan Yogyakarta

Suharsimi Arikunto. 1996. Prosedur Penelitian Suatu Pendekatan Praktek. Jakarta: PT Rineka Cipta. 